\title{
The existence of the evil in the world: a challenge for Philosophy and Theology
}

\author{
PhD. Prof. Leontin POPESCU, \\ Faculty of History Philosophy and Theology \\ "Dunărea de Jos" University of Galați, \\ ROMANIA \\ E-mail: prleonpopescu@yahoo.it
}

\begin{abstract}
The existence of the evil in the world is maybe the most difficult problem man has tried to decipher all along his history. The fundamental question which has been asked during all this time has been WHY? And comprises either the search of an explanation (What for? What is its cause?), or the search of hat is it good for? Where can it take us?). It is clear that beyond any philosophical, moral, religious, social etc., category, which could lead us to deciphering this notion - the evil-, one thing is certain: the man experiences the evil in its different forms: physical, psychological, moral sufferings, cataclysms and earthquakes, totalitarianisms and fanaticisms. Philosophy, religion, morale-humanities, in general, have tried along the time to find an explanation and even a definition of the evil, but none has absolutely succeeded in finding a definitive explanation. And this acknowledgement makes us think that the evil has something beyond the whole created nature of man and universe and through this, it cannot be defined. Even if man and universe feel its consequences, it exists not as something given, but as possibility.
\end{abstract}

Keywords: the evil, well, original sin, origin, human nature

\section{INTRODUCTION}

Since the beginning of their evolution, philosophy and religion have never ideated evil as an opposed reality to good, but they have interpreted it as "not being", as an absence of "to be", as "non-existence" [1]. And this applies to both Western and Eastern civilisations. The evil does not exist as an ontological principle [2], but it appears as subjacent, it "steals" [3] its subsistence from the Good, it is the abandonment of the Good. Saint Gregory of Nyssa says that this abandonment of good led to the appearance of all forms of evil [4]. The structure of evil is antonymic. The Evil is a void of the nothing, but a void which exists, which swallows and devours beings. The Evil is devoid of power; it never creates anything, yet its power is enormous. The Evil has no substance, it is perceived as the absence of what should be present, it arises where no good is manifest. It is an accident, a parasite of the good, "a deformity", "a disease" of the being, as it is characterized by Berdyaev [5]. This state produces suffering because the nature of the good is to be, and if the unity of to be is broken, then a coil of the ontological nature is triggered; normalcy undergoes a mutation, which, in turn, can generate another mutation, leading to an endless pattern, which distorts 
the natural essence of things, that is good. Nevertheless, this alteration, this mutation that has brought the evil, has its origin in liberty, in the freewill which God gave to all his creatures: men and angels. The Evil does not spread into the world without liberty and is not maintained without its consent. That is why it may be said that evil doesn't rise from the being and it is not tied to it. That is why, the evil can be said not to spring from a being and it is not tied to it [6]. It is only this way that we can understand it to have a cause, i.e. the possibility to choose - the freewill [7]. The evil that has no subsistence in itself [8], is parahypostasis [9], comes into existence in the beings endowed with freewill, who give up the Good. According to the Holy Fathers, the evil has no cause, it has neither definition, nor it is in conformity with nature [10]. It does not pertain to any given nature, but to the changing nature [11]. Therefore, either natural or moral the evil is man-provoked. From the disobedience of Adam and Eve, the first proto-parents who were given their freewill, there come into this world all of the evils. The unique source of Sin, in the strict sense of the word, is the will [12] to oppose God and the tragic alienation from Him. To give up what is Supreme means to begin having a bad will [13]. The true will always chooses God, and abandoning Him implies the vanity of being autonomous, independent.

As a consequence of the sin of the first man, disorder establishes both among the beings of creation and in man [14] as well. The creation had been meant to be good [15], not in the sense that it was good by itself, but due to its participating at the life of the Good, it could thus become good. The more, as the human being and the world were not created by the nature of God himself, where there is no mutability, but out of nothing, the longer the creature was expected to stay in communion with the Creator, as a Source of the Good [16]. The meaning of Creation lies in its on-going active participation at the dynamic presence of God. And it is by this reason, situated at the opposite side, that the evil is seen as an illness of the human being who has lost the communion with God [17]. Disobedience - this great disease - that has affected mankind, has reached its forms of existence, men themselves living between God and everything that was created as a connection with God's whole creation [18]. The origin of the Evil lies in the freedom of existing creatures [19], it is a personal attitude [20]. The evil attacks all the structures of the created beings, and is the corruption of creation [21] and hence, the conception of the orthodox patristic regarding the origin of the Evil according to which it has no consistency in itself and the world and matter are not bad in themselves as the Manicheans would believe it, but they may be considered good through their own creation.

This illustration for the reason of the Evil in the world through the free will and the Original sin has its origin in the Christian tradition and finds itself good display not only with the Oriental begetters but also with those of western regions, especially through Saint Augustine [22]. Unlike the western regions where there prevails the opinion according to which the starting point of the sin, illness and death is the Original sin, as well as the starting point of the incarnation of the Son of God [23], the eastern regions consider the Original sin to genuinely be a central event the history of humanity, but which cannot be accepted to be the centre of creation and of the salvation of man [24]. If Western scholasticism relates the 
process of Jesus' embodiment to the Original sin [25], Eastern patristic has always considered the salvation of men, the salvation from the sin to be independent from the Original $\sin [26]$. In the view of the Eastern theology, the Original sin is seen as some form of illness, a weakness or an infirmity and there is no mention of hereditary guilt, but just of a special kind of heredity of moral corruption and death [27]. For the human nature, Adam's sin meant the getting of disease and harm. Through committing the sin the Man has lost that primordial condition of non-suffering since the moment of his genesis and he has got not the tendency towards angelic life, but contrary to this, the tendency to obey to the bodily part, to obey to the dust he was made of [28]. The result of the erroneous use of freedom given through creation, the sin has brought about the corruption of matter, the key elements that made it ephemeral and harmful.

Through sin, humanity undergoes a double estrangement: on the one hand from God, as it is seen from the attitude of the proto-parents who sought to hide from God, the Creator, and on the other hand from the environment in which they were laid upon, with which they had not felt intercommunion. The enmity between the natural world and the human nature displaced harmony since its earliest beginnings. Man started dominating and exploiting to fulfil his own needs, which he selfishly interpreted, wiping out the sense of ponderation in parallel with the growth of greed, which became a preoccupation of reference in the history of humankind. The rot and decay has taken its ultimate form in death and decay. The fear of death brought angst, anxiety, passion, greed, hatred and despair to man. The need to escape death has made him look even more insistently for material elements which could make him forget about it. Exploitation took forms which were peculiar to each historical era. The economic exploitation, racial oppression, social inequities, war, genocide are all consequences of the fear of death and a collective sign of death.

\section{The primordial sin and its consequences upon the first family, Adam and Eve}

The fulfilment of the proto-parents on the road to their accomplishment lay in their capacity to use the command in their favour and in the favour of the whole creation as bearers of God's image. Following God's command "thou shall not eat from the tree of wellbeing and evil knowledge" (Genesis 2, 17). Before their downfall, Adam and Eve being themselves one family who aspired to perfection, attended each other by obeying God's command, preventing the breaking of the bond with the Creator, and contributed to preserving the heavenly happiness. The life of Adam and Eve did not limit itself only to a beastly and biological expression, wherein fulfilment means only the strict satisfaction of their own needs, but was manifested through synergic work between man and God, between reasonable and Rational, manifested through progressive and gradual confession of the human being, since "God, our teacher, gave us this great command, that we achieve with the help of reason what the animals are doing by instinct, he commanded us that the ones instinctively perpetrated by animals we should do with great care and continuous surveillance of thoughts" [29]. 
Both their soul and their body participate at our proto-parents' divinization, since they are dichotomist human beings, and so the committing of the sin of disobedience was carried out at first at a rational level, with the thought and later on with the body. So, not just the body is guilty of their downfall because the body too was created by God and it was created like all the other "genuinely good" (Genesis, 1, 31). In this way, to demonstrate that the body is not evil through its nature and is not a source of evil's, the authorities of the church bequeathed a teaching saying that the body is not the source of the evil in man: "the body is innocent towards those who tried to charge it of being the head of evil doing" [30]. The body, part of the human being is not the centre of evil, but a means of manifestation of the soul in this material world, through which it can materialize its actions "for the body has not received its natural instincts without a reason, but generally for the ones which are good and useful to each of us" [31]. God did not create man as automatic machinery, but as a free subject able to master the processes of his own nature to which HE WAS TO PROGRESS towards the good [32]. The materiality of the body is not a source of evil inside man and neither is it responsible for the good or the evil made by the man carrying it, "for if it is the soul that which controls the movements of the body, directing it towards the good and towards the evil. The soul can save or punish the body, if the soul uses rottenness; for if the soul uses properly the instincts of the body, it also saves the body and finds itself outside danger. But if it neglects the Creator's work and is seized with the sleep of negligence, it will abandon the guidance of the body, and being deprived of rational thinking, it distances from the right road and it allures the soul towards the same evil, not out of its own wickedness but because of this indifference of the soul" [33]. Therefore, the human body is guided by the rationality of its soul, rationality without which the body cannot exist. Man's choice to tie himself to the earthly or to the heavenly belongs to the soul, becoming bodily or heavenly individual.

The moment when Adam and Eve decided to take the advice of the servant instead of the Godly command, trying to become god outside God [34], there began a process of diminution of their state of grace and communion, a communion with their own nature and with God which was lost „,because of the breaking the command, being deprived of the help from the almighty" [35]. Nevertheless, they began to be predominantly attracted to materiality "and they both had an epiphany and they both became aware of their nakedness" (Gen. 3, 7). This new condition of existence of the first man was defined by the orthodox anthropology on the basis of the revelation from the Holy Scripture, as the living in "clothes of skin" [36]. The nakedness Adam and Eve felt was not related only by the fact that they had no clothes on, but more than this what matters is the fact that they stood deprived of the grace of God, by the almost unlimited access to the source of Wisdom "in such a gap did the breaking of the Lord's command brought them. They who sometime before had enjoyed such a high audacity, they who did not even know they were naked - for they were not naked, since the supreme greatness would cover them better than their coat-after they ate, that is after they had broken the command, they stooped so low that they looked for a cover for they couldn't bear the shame any longer" [37]. Man no longer has a life which is part of his own 
nature, he does not exist due to life, which naturally springs from the insight, but he exists for he cancels death [38].

Those who live in Christ a life which is superior to the bodily one - the new Adam, like the ones who have received the Godly grace and have chosen to follow the advice of the soul reason - are those who placed the concern for the body after soul making it a priority, e become spiritual persons "for when the soul - as stimulated by its own intelligence which was naturally planted within himself by the Holy Trinity upon his creation - ponders to the pleasant and the necessary, then he immediately frees himself from the harmful influences of the body" [39].

The man becomes spiritual by training the force of the soul through the body. The spiritual work of the spiritual climbing involves a physical effort from the one who wishes to follow this path of ,the one who wish to write their names in the book of life" [40]. This effort begins gradually from the simplest of the tasks to the more and more complex as man advances in apprehending God and in the battle against enemies of our redemption "for our fight is not against the body and the blood, but against beginnings, against domination, against masters of the darkness of this century, against the ghosts of evil which are in the sky" (Ephes. 6, 12).

Since the very moment of its making by God, the body was a direct component of man as a whole being created in tight unity with the soul. Before the downfall the adamic body was immortal, indestructible, spiritual, being "lord and emperor of the whole seen world" [41]. Therefore the man was created without evil instincts and the tendency towards the good of the communion with God and his peers, but not strengthened in this purity and this good [42].

Through the sin of disobedience that was accomplished by our proto-parents, the body took a new form, becoming open to impurity ,doomed to live in ephemeral body and to die" [43]. Deprived of God's praise, the human body took a new form, becoming thus prone to decays of all kind, ,was alighted from Eden due to disobedience towards rottenness" [44]. This decay has deprived him from the wisdom with which he was endued with when he gave name to animals, but has not only become unskilled, but has also somehow acquired likeness between animals using the intellectual skilfulness that was left during the hunting for other enjoyments, being guided by the desire of senses in quest for matter [45]. But the satisfaction of the senses has the thick end of the stick, pain, a measure taken by God as a punitive counterbalance which accompanies the life of the human being after downfall.

The man, guided by the devil, seeks to enjoy as much pleasure as possible by trying to avoid pain. Although pain cannot be avoided, it leads to gradual deliberate degradability of the human body, which is tied to the Holy Ghost "Don't you know that you yourselves are God's temple and that God's Spirit dwells in your midst?" (1 Cor. 3: 16). Pain and degradation brought forth to the body due to excess is also felt by the soul, the latter not being able any more to manifest itself because the body „, when is weak and somnolent by the material pleasures, does not let the soul fulfil its mission spiritually" [46]. 
Human nature fallen into decay is inclined to self-love. Therefore, all the energy supposed to be leveraged towards the Creator, as a reply to His love „for He was the first to have loved us", is aimed at satisfying our own animal instincts, which does nothing else but to fester the body, and ,the tormented body is as paralyzed as a shipwreck" [47]. The body, wrecked by its own desires, wishes to become responsible by misuse of what has been gifted for good calculation. God speaks of this evil misuse, consciously and deliberately effected of the human body through the preaching of Saint Apostle Paul: „If anyone destroys God's temple, God will destroy that person; for God's temple is sacred, and you together are that temple" (1 Cor. 3, 17).

The soul, being part of the human being, has been, is and probably will be a matter of religious controversy. Is is certain that in the Christian world, the soul is unanimously acknowledged as being part of the human race. If Christianity sees the existence of the spirit within the human body in almost all regards, then when it comes to its origins, opinions are different. The Origenism sustains the idea that the spirit might have been existed long before conception of the body, The traducianism that it could originate from the parent's soul and finally, the orthodox traditionalism states that, according to the truth revealed in the Holy Writ, human soul is created the moment conception takes place of the human body: "the body and the soul are part of the human being, [...], are form among those which have always and anywhere have come into existence together" [48]. When we refer to a human person, we refer both to his material side, the body, and to his immaterial side, the soul, for ,it is not perchance all over creation to name or discover anybody or soul without their own relation" [49].

According to the pre-existentialist theory, if the soul had existed before the body, this means that man, as an individual or as a person, is made up of two entities, different from each other, that is the body would be only a recipient or a prison for the soul, and the latter would have a symbiotic existence together with the body, in the physical world. As it is an independent entity pre-existent to the body, the soul cannot form one unity with the body, because "that which pre-exists itself in extraordinary state can never be reduced to to the hypostasis of another species" [50]. Thus, if the soul pre-exists the body, as a distinct and complete being, then when one is added to the one created afterwards, it cannot form a unity with it, it cannot complement it, because "if everyone gets, against their own nature, the composing with the other to the replenishment of another species, they are certainly corrupt, breaking their own boundaries and becoming what they are not by their nature and falling in what they were not" [51].

God created Adam with body and soul. He made his body from dust "the LORD God formed a man from the dust of the ground" (Gen. 2, 7), and for his soul, "and breathed into his nostrils the breath of life, and the man became a living being", (Gen. 2, 7), thus, Adam received the soul after his body had already been made, but this does not stand as an argument in favour pre-existentialism. In these verses from the Book of Genesis, we are shown that the body and soul are not consubstantial and that they were not created in the same way, and their unification in the person of Adam "happened in a secret way" [52]. The 
fact that in the Book of Genesis, in the act of creating Adam, there is a word which says that at first his body was made and afterwards his soul, does not mean there was a time when Adam's soul did not exist in his body, but it is only a materialization of God's hidden work, so as "the reason of substance of each and everyone and the extraordinary way of the genesis should be acknowledged" [53]. Although, the way God created the first man remains a mystery to us.

The orthodox tradition speaks about the value of the soul in relation with the body, saying it is "a lot more superior and so different from it, as the bodily is to the spiritual" [54]. The value of the soul is the man's value itself, for "we belong to it entirely, it is everything to us, and we can neither live, nor die without it" [55]. Without the awareness of the value of the soul, man cannot die from the sin and then resurrect and live a real life. The true living is the acceptance of the fact that we do not belong to ourselves and that we are recipients for the holy grace, as Saint Paul the Apostle said: "Do you not know that your bodies are temples of the Holy Spirit, who is in you, whom you have received from God? You are not your own?' $\left(1^{\text {st }}\right.$ Cor. 6,19). The conscientious, free and unconditional acceptance of the fact that we belong to our Creator and we therefore are the result of absolute love opens a path to eternal happiness for us.

Inevitably, after the natural end „each soul is defendant and witness, as much defendant of sin as is a witness of truth and he will stand in front of God without anything to say on his doomsday" [56].

The damnation or recompense of his soul in the afterlife is given depending upon the choices made during the earthly life. The man has the free will to choose either to transform his body into a prison of his soul, ignoring and letting him to starve for spiritual grace which is God's gift, and the consequences lie in the fact that "the one who seeds in his own body, evil will harvest from the body" (I Cor. 6: 19). If the man chooses to transform his body into "a temple of the Holy Spirit" (I Cor. 6, 19), he will benefit from His fruit for "he who seeds in the Holy Spirit, from the Holy Spirit will scythe eternal life" (Gal. 6: 8).

The consequences of this transformation, from the spiritual to the material, which Adam and Eve have undergone and which were transmitted through them to the whole humankind, were the feeling of the forces of nature as crowns of creation: "cursed will be the earth because of you!" (Genesis 2: 17). The evil takes contagious proportions, nature and everything which surrounds man is in opposition and division. Disease, destruction and disorder are produced at the same time, nay, they are also extended and multiplied, and from a master of creation man becomes its slave [57]. For God wants all people to be saved, he does not allow the powers of evil to sink His creation. Man and nature remain protected by his Holiness. Although he lost his resemblance with God, the man remains a bearer of God's countenance, even if the latter is deformed; the man is not totally devoid of grace, but he has enough spiritual power in his weakness, to come, if he wants back to God again [58].

\section{The origin of evil}


Taking into account what has been said in the foregoing, we legitimately return to the question: which is the origin of evil? Man or God?

We have seen that man is not the origin of evil unless viewed from the perspective of freedom; man is a victim [59] of the one that created the evil. Nobody chooses the evil as evil. Nevertheless, we must admit that each of us carries on the consequences of the corruption of evil and admits himself as the author of his own wrongdoing [60]. The orthodox theology does now view the original sin as heredity nor as punishment of man for his disobedience of the commandment of asceticism, but the evil as a disease, it is the corruption of the reality which was created good. Everything that is delicate and spiritual was created good, but because of the status of creature made from nothing, each is in danger of heading towards nothingness. This is what evil is exactly about: the alteration of reality which leads to the corruption of the one who was created good. However, this sin-ensued corruption is passed on to all the people, not in the sense that they are all inheritors of the original sin, of Adam's sin, but the corruption caused by the sin is biologically passed on from generation to generation, as it is stated by St Maxim the Confessor: Man receiving life from God and coming into existence through the act of creation, was free from corruption and sin, for these were not created at the same time with him. But when he sinned by breaking the commandment, he was punished with pain in childbearing, which is continued by sin, the sin having its source in the passionate feature resulting from his own doing, as in a law of nature. Because of this law no man is without sin, being subject by nature to the law of birth, which was introduced after creation, because of the sin [62]. Commenting on this text in Filocalia Română volume 3, father D. Stăniloae speaks about the propensity to sin of the human nature after the original sin, almost as a law of nature [63]. Therefore, at birth every man inherits Adam's sin-corrupted human nature: sick, crippled, marked by the consequences of sin [64] and not by Adam's sin. Through the law of our descent from the first pair of humans, the "human condition" is passed on, but this is a decayed condition, which every man renews, starting with the act of his biological birth [65].

Neither is God the evil doer. The whole eastern tradition regarding the genesis of the world and man agrees to say that "God is the creator of all the seen and unseen", but not creator of the evil. In a famous homily [66], Saint Basil the Great says: "God is not the creator of evils" and that only a careless and unwise mind could come in conflict with the Lord's goodness and portray Him as the author of the evil, sin and death [67]. Saint Basil the Great says "Do not take God to be the cause of the existence of all evils, and neither do you imagine the evil to have a life of its own. Because the evil has not got a subsistence like any other ordinary, independent and autogenic animal. For the evil is an absence of the good. The eyes were created, but blindness occurred later through the loss of the sight. Therefore, if the eye had not been constructed from a frail material, blindness could not have occurred. In a similar way, the evil has not got its own subsistence, but is an outcome of the pains of the soul wounds. Evil is uncreated, as the heretics sustain, giving the same value to the evil and the nature of the good, considering that both the good and the evil were without a beginning and eternal and prior to the genesis of the world; but not created either. If 
everything comes from God, then how is it possible for the evil to derive from the good? Neither the ugly derives from the beautiful and nor the vice from virtue" [68]. All of the eastern [69] and western [70] Holy Parents agree with Saint Basil's words saying that God is God is not the creator of the evil [71], each bringing arguments to provide as plausible an explanation to this antinomy as possible: the existence of God and the existence of the evil. The Patristic theology has tried an explanation regarding the way evil appears through the created and changing character of the creatures as compared to the non-created existence of God [72]. That is through the understanding of the two existences: God and the world. St Basil the Great contradicting Eunomie through the existence of the uncreated energies which are present in this world, states that two are the things that remain behind: "divinization and creation, dominance and bondage, the power which makes things holy and the power that is holy" [73]. This essential distinction underlies the alterity between God and the world. The world exists because of the communion with God, and it is continuously getting from Him the properties and the possibilities for its own development [74]. Grace to this participation to the holy life, the creation becomes reality [75]. Since God creates existence out of nothing (ex nihilo), the world stays in communion with God as long as they follow His lead, otherwise, because of his condition as a creature, he would go towards nothing. This thing gives the world the need of change, of evolution, which can be towards good choosing God, or towards nothing, while God always remains unchanged. Augustine [76] his eminence, explains why God, in his nature, is above all things and beings, because of the very creation of all things from nothing, all being good, but nevertheless, changing, otherwise, if all things were done from the nature of God, "not a thing would have been subject to sin"[77]. Only God exists from Himself, through his own essence, all the other things are good through their participation to the goodness of the godly nature [78]. If all were created from the godly nature, then all would be good and it wouldn't be any difference between any creature and the Creator, thing that would lead to mistaking the creature for God and we would fall into the deepest pantheism [79].

Although the Holy Scripture tells us that at the end of the genesis God looked at everything He had done and the all were very good (Genesis 1, 31), this does not mean that the world, the angels, the man were brought to existence in the state of perfection. In this regard, Saint Irenaeus says that "those newly born are necessarily inferior to those unborn. For they are not unborn, that is why they lack perfection" [80]. But neither the relative, changeable character of the being should be considered as an evil in itself, for it is only on the way of changing that the being can progress. It is only in this way that we can understand that the universe created by God is not perfect but through participation [81] which is not momentary and static but continuous and dynamic. According to the orthodox theology, each being comes into existence from the non-created, that is not from the divine nature [82], has two features: it is moving and perishable. It moves towards perfection through participation, or towards estrangement which can go as far as to disappear. Flexibility, mortality, and corruptibility are conditions of the created [83]. God only, for He is non-created, immutable, eternal, immortal [84] cannot lose His being [85], while the being through his free will can 
lose it and change it [86]. The being, through its attribute of being created, through the fact that he has the possibility of changing does not mean that it is evil. That is, there is no metaphysical evil, or else we should attribute the cause of evil to the Creator, which contradicts God's Kindness and Almightiness [87]. As a consequence, any being coming from God's hands is good in its own way [88]. The evil cannot exist but in a created existence [89].

\section{CONCLUSION}

By way of consequence, the appearance of the evil and of its angels is accounted for through the fact that also the bad angels, who in the beginning were like all the angels spiritual beings created by God before the man was created - were subject to the same conditions of the ex nihilo creation, namely the condition of a being: moving and relative in their perfection. Anything which is comparable with God, the only incomparable, bears within itself the gift of creation which is relativity. Whether we talk about the world of the angels, which, as it is defined by theology, is a spiritual world, as compared with God, it gains a material character [90], or we talk about the wholly created world, that is the bodily, and the material, they all distinguish from the Creator through the desire of change. Angels, in turn, have the same propensity towards progress in grace and virtue. They rarely show a bias to the evil, but they are not unbiased. "Lucifer - says St. Basil the Great [91] had not fallen down and had not crushed against the earth if he had been incapable of bad out of his nature." Incapable of evil, unchangeable, unharmful is only god the uncreated. Everything which is created can spoil [92]. Satan with his devils, submitted to any change, good or bad, revolted against God out of their envy to become like God, that is a source of existence [93], and they lost communion and grace becoming perverted and bad beings of the genesis. The same St Basil the Great wondering where the evil of the devil comes from, answers that from the same cause, namely because of the desire of change of will. And Satan, like all the angels, and like Archangel Gabriel, had a free life and through his liberty had the possibility to stay by God or to estrange from God. "This is the evil - says St. Basil - the estrangement from God". And he immediately makes a comparison with the one who faces the sun and illuminates himself and who hardly needs anything else but a moment to turn back and enjoy the shadow and necessarily the dark [94]. The same thing happened with Satan, just one moment sufficed for him to wish for his independence and to fall like a lightening.

And in this regard, of the role played by the devil in the fall or the salvation of man, the orthodox theology is different from the western theology. If the western world beginning with Saint Augustine [95] disregards divine philanthropy considering the devil to be the instrument for the man's punishment, the orthodox theology considers man to be a victim and naturally, the death-tempting subject. And this leads to the necessity of practising asceticism on the part of the man on his way towards perfection, while the divine help shows itself in the wiping away of the devil's idolatry temptations. Man uses his free will for the very purpose of rejecting all the malignant attacks, in practising asceticism, and fundamentally to accept God's gift of help [96]. 


\section{REFERENCES}

[1] Fr. prof. Dumitru Stăniloae, Teologie Dogmatică Ortodoxă (Orthodox Dogmatic Theology) vol. I, București, Edit. Institutul Biblic și de Misiune (I.B.M.), 2003, p. 474.

[2] Georgios Mantzaridis, Morala Creștină (Christian Morale) translated from Greek by Cornel C. Coman, București, Edit. Bizantină, 2006, p. 47.

[3] Nikos Matsoukas, Teologia Dogmatica e Simbolica Ortodossa, (Dogmatic and Symbolic Orthodox Theology) vol. 2, translated from Greek into Italian by Eleni Pavlidou, Roma, Edit. Dehoniane, 1996, p.111.

[4] St. Gregory of Nyssa, Oratio Catechetica, cap. VIII, in J.P. Migne, PG. 45, col. 39C:'But started now when the changing nature did not meet any more obstacle, abandoning the good, the man affirmed himself in the evils contrary to him. The good was replaced with its opposites the way death is opposite to life, the dark is opposite to light, the vice to virtue, instead of all the good things, through reference had all the (free translation); ("Cum ergo in his quoque esset homo, cui naturae mutabilitatis dilapsa erat ad contrarium. A boni autem recessus et a consequenti omne genus mali induceret, adeo ut per aversionem quidem a vita, ejus loco mors succederet, per privationem autem lucis, tenebrae, pro absentia autem virtutis, inveherentur vitius in locum autem amnium bonorum referretur numerus contrariorum")

[5] Nikolai Berdiaev, Esprite et liberte: essai de philosophie chretienne, traduit du russe par I.P. et H.M, Paris, Editions Je sers, 1933, p. 182.

[6] D. Stăniloae, Teologie Dogmatică Ortodoxă, I, 2003, p. 474.

[7] St. Gregory of Nyssa, In Ecclesiasten, Homilia VII, in J.P. Migne, PG, 44, col. 726C: "Malum extra liberum arbitrum in se ipso non est situm".

[8] Dionysius the Areopagite, De divinis nominibus, în J.P. Migne, PG. 3, col. 586-997: very well debates this problem of the existence of the Good and the Evil, showing as far as we are concerned that the Evil "has no existence in itself and is not a generator of existence", the existence is attributed only accidentally; "The Evil does not exist as evil"; "Ad haec autem vera ratio respondebit, malum qua malum nihil conferre ad essentiam aut rerum generationem,..." (De divinis nominibus, IV, 20, PG. 3, col. 718C); "Malo status tribuiendus est per accidens ..." (De divinis nominibus, IV, 32, PG. 3, col. 731D); "Nusquam enim malum est, qua malum"; (De divinis nominibus, IV, 34, PG. 3, col. 734D)

[9] Nikos Matsoukas, Teologia Dogmatica e Simbolica ..., p. 111.

[10] Dionysius the Areopagite, De divinis nominibus, XXX, col. 731A: "Malum autem si causae sit ac definitionis expres, non est secundum naturam".

[11] N. Berdiaev, Esprite et liberte, p. 182.

[12] St. Augustine, De Genesi contra Manichaeos, în J.P. Migne, PL. 34, col. 188.

[13] Constantin C. Pavel, Introducere în gândirea Fericitului Augustin (An Introduction to the thinking of Saint Augustine), București, Anastasia, 1998, p.140.

[14] Jean-Claude Larchet, Teologia bolii, traducere din limba franceză de fr. prof. Vasile Mihoc, Sibiu, Edit. Oastea Domnului, 1997, p. 30.

[15] St. Augustine, De natura Boni. Contra Manichaeos, cap. I, în J.P. Migne, PL. 42, col. 551: "But the whole nature which exists is good" (free translation);; ("Omnis autem natura in quantum natura est, bonum est").

[16] C. C. Pavel, Introducere în gândirea Fericitului Augustin, p.106.

[17] Fr. prof. Vasile Răducă, Antropologia Sfântului Grigore de Nyssa (Anthropology of St. Gregory of Nyssa), Bucureşti, 1996, p.176.

[18] St. John Damascene, Expositio Fidei Orthodoxae, II, 30, în J.P. Migne, PG. 94, col. 978D.

[19] St. Basil the Great, Homiliae: Quod Deus non est auctor malorum, în J.P. Migne, PG. vol. 31. col. 330-354, aici cap. 5, col. 338D-339A: " Malum igitur quod proprie dicitur, peccatum videlicet, quoqae maxime mali nomine dignum est, pendet ex nostra voluntate".

[20] Vladimir Lossky, Introducere în Teologia Ortodoxă, București, Editura Enciclopedică, 1993, p. 110.

[21] N. Matsoukas, Teologia dogmatica e simbolica ortodossa, 2, p. 113.

[22] St. Augustine, De libero arbitrio, in J.P. Migne, PL. 32, col. 1221-1310.

[23] Idem, Sermones 174, II, in J.P. Migne, PL. 38, col. 940: "Si homo no perisset, Filius hominis non venisset. Ergo perierat homo, venit Deus homo, et inventus est homo. Perierat homo per liberam voluntatem: venit Deus homo per gratiam liberatricem" (free translation: If man had not perished, the Son of manwould not have come. Lost was the man through free will, God came embodied through the liberating grace)

[24] N. Matsoukas, Teologia dogmatica e simbolica ortodossa, 2, p. 105-106. 
[25] St. Anselm of Canterbury is the one who develops this option in his treatise Cur Deus homo, în PL. vol. 158 , col. $360-432$.

[26] St. Athanasius the Great, De incarnationem Verbi, în J.P. Migne, PG., vol. 25, col. 192B: "Ipse siquidem homo factus est, ut nos dii efficeremur"'( He took his body for us to reach divinisation - free translation).

[27] St. Cyril of Alexandria, Explanatio in Epistolam ad Romanos, în J.P. Migne, PG. vol. 74, col. 789AB.

[28] St. Athanasius the Great, De incarnationem Verbi, PG, 25, col. 103.

[29] St. Basil the Great, Homilies and speeches, Homily III, translation, introduction, notes and indices by D. Fecioru, in the collection " Church Fathers and Writers" (RPW) in the collection "Church Fathers and Writers", vol. 17, Bucureşti, Edit. I.B.M, 1986, p. 366.

[30] Idem, Constitutiones Asceticae (monasticae), cap. II, în J.P. Migne, PG. 31, col. 1343B : "Corpus ab iis qui ipsum velut pravitatis auctorem criminari conantur, nequaquam culpari potest".

[31] Ibidem, cap. II, col. 1342D: "Corpus enim naturales impetus sortitium ineptos, sed prorsus ad aliquid idoneos ac utiles".

[32] D. Stăniloae, Teologie Dogmatică Ortodoxă, I, 2003, p. 430.

[33] St. Basil the Great, Constitutiones Asceticae, cap. II, PG. 31, col. 1343A: "Ipsa enim si impetus corporis rite gubernarit, et ipsum servat, et ipsa caret periculo: sin jus negligat regendi. Et segnitiei somno victa, gubernationem corporis deseruerit, et ipsum veluti ratione destinatum, a recta via aberrat, et animam in eamdem ruinam detrudit non ex sua ipsius pravitate, sed propter illus socordiam".

[34] J-C. Larchet, Teologia bolii, p. 26.

[35] St. John Chrysostom, Omilii la Facere (Homilies on Genesis), I, in PSB. 21, București, Edit. I.B.M, 1987, p. 183.

[36] The Holy Parents have not dealt this conception in particular, but they remember it in their writings. Why this denomination: "clothes of skin"? Through this term, the orthodox theology, not as much as a fall of man in sin as Adam's ,transmutation” as well as that of the following generations in a world considerably inferior to the paradise state, a world of degradation and automatism of material nature. According to the Greek theologian Pnayiotis Nellas, among the Holy fathers who have such an approach (Omul animal indumnezeit, Sibiu, Edit. Deisis, 1999), is St. Gregory of Nyssa,( De hominis opificio, în J.P. Migne, PG. vol. 44, col. 123-247; In Cantica Canticorum, PG. 44, col. 755-1118; De Verginitatem, PG, vol. 46, col. 317-416; Oratio Catechetica, în J.P. Migne PG. vol. 45, col. 11-107) St. John Chrysostom ( Homiliae XXX in Epistolam secundam ad Corinthios, in J.P. Migne, PG. vol. 61, col. 381-610; Homiliae in Genesim, PG. vol. 53); St. Gregory Palamas (Homiliae XXX), în J.P. Migne, PG. vol. 151, col. 375-388)

[37] St. John Chrysostom, Omilii la Facere, I, p. 183

[38] Pnayiotis Nellas, Omul animal îndumnezeit (The Man, the divinised animal ), introductory study and translation from Greek by Ioan Ică jr., Sibiu, Edit. Deisis, 1999, p. 87.

[39] St. Basil the Great, Constitutiones Asceticae, PG. 31, col. 1339A: "Et enim animus quando sua intelligendi vi commota, quae ei naturaliter a sancta Trinitate ipsius opifice insita est, de rebus, que et ad officium pertinent, et honestate sunt, deliberat, tunc corporis assultus effugit"; ("For when the soul - as it is stimulates by its intelligence, which was planted in it naturally by the Holy Trinity when it was created ponders on the much pleasant and the necessary, then, as soon as it is freed from the harmful influences of the body" - translation by Iorgu Ivan: St. Basil the Great, Ascetic Constitutions, Apologeticum, 2004, p. 10.

[40] St. John Climacus, Ladder of Divine Ascent, word I, în Filocalia, vol. 9, translation, introduction and notes by Dumitru Stăniloae, Bucureşti, Edit. I.B.M, 1980, p. 41.

[41] [41] St. Symeon the New Theologian, Cuvântări morale - întâia cuvântare morală ( Moral speeches the first moral speech), in Filocalia, vol. 6, translation, introduction and notes by Dumitru Stăniloae, Bucureşti, Edit. I.B.M, 1977, p. 121.

[42] D. Stăniloae, Teologie Dogmatică Ortodoxă, I, 2003, p. 428.

[43] St. Symeon the New Theologian, Cuvântări morale, p. 122.

[44] Ibidem, p. 128.

[45] St. John Chrysostom speaks about material lust which changes man into an animal and he gives the very example with the man who can become like a pig, in Problemele vieţii (Life issues), translated by Cristian Spătărelu şi Daniela Filioreanu, Galaţi, Egumeniţa. p. 149.

[46] Ibidem.

[47] Ibidem, p. 150

[48] St. Maximus the Confessor, Scrieri, partea I, Ambigua (Writings, part I, Ambigua), in P.S.B, vol. 80, translation, introduction and notes by Dumitru Stăniloae, Bucureşti, Edit. I.B.M, 1983, p. 98.

[49] Ibidem, p. 100. 
[50] Ibidem, p. 276.

[51] Ibidem.

[52] Ibidem, p. 277.

[53] Ibidem.

[54] St. John Chrysostom, Omilii la Facere, I, p. 139.

[55] Tertullian, On the Confession of the Soul (De testimonio animae; ), în P.S.B, vol. 3, translated by Nicolae Chițescu, Eliodor Constantinescu, Paul Papadopol and David Popescu, introduction, notes and indices by Nicolae Chiţescu, Bucureşti, Edit. I.B.M, 1981, p. 124

[56] Ibidem, p. 125

[57] J-C. Larchet, Teologia bolii, p. 31.

[58] Ibidem, p. 32.

[59] N. Matsoukas, Teologia dogmatica e simbolica ortodossa, 2, p. 108.

[60] St. Basil the Great, Homiliae II in Hexaemeron, în J.P. Migne, PG. 29, 40A

[61] N. Matsoukas, Teologia dogmatica e simbolica ortodossa, 2, p. 111.

[62] St. Maximus the Confessor, Quaestines ad Thalassium de Scriptura sacra, Quaestione, XXI, în J.P. Migne, PG. vol. 90, col. 244-785, aici col. 312C-313A: "Primus homo, accepto a Deo ut esset, ortuque editus ac reatus, ipso suo ortu et creatione, liber a corruptione et a peccato fuit. Non enim corruptio et peccatum, pari cum illo ortu creata sunt. Ubi autem mandati transgressione peccaverat, nativitati reus addicitur, quae passione ac peccato consistat; ita nimirum ut peccatum, in patibili eius causa inducto, iam velut in lege per naturam ortu habeat: vi cuius nemo a peccato immunis est, subjecta natura nascendi legi, quae a primo ortu ac creatione, peccati reatu supervenit".

[63] D. Stăniloae, Nota 132 (Note132), în "Filocalia Română”, vol. 3, Digitally signed by Apologeticum, 2005, p. 87-88: "The passions are afected, once they have become part of the human nature after the sin.they are not sinful, but they facilitate the birth of the sin. For instance, appetite is a sinless effect. But extraction or its deviation is a sin. They have become a sort of law of human nature, that is they necessarily accompanybour nature in earthly existence. They do not pertain to the eternal ideea of nature and so they will not belong to him in his celestial existence.".

[64] J-C. Larchet, Teologia bolii, p. 34.

[65] Ioan C. Teșu, Bolile-"Divina filozofie". Suferința - "Pedagogie divină" (Diseases-"Divina philosophy". The Suffering - "Divine Pedagogy"), in the review "Theology and Life", no. 1-4(2012), p. 8.

[66] St. Basil the Great, Homiliae: Quod Deus non est auctor malorum, 2, PG. 31, col. 331B:" Itaque qui dicit Deum non esse, insipiens est et stultus, cum vere mente privatus sit atque prudentia. Assimilis autem huic est, et nihilo stoliditate inferior, quisquis dicit Deum malorum esse auctorem".

[67] Ibidem, col. 344A; 345A: "Nam si auctor est malorum, utique nec bonus est, ideoque utrinque negatur Deus".

[68] Ibidem, 5, col. 341C: "Uno verbo, neque Deum substantiae mali auctorem esse putes: neque mali ullam esse propriam subsistentiam fingas. Non enim subsistit, velut animal quoda, privas: neque illius essentiam vere exsistentem ponere ob oculos possumus. Nam boni privatio malum est. Creatus oculus est, sed oculis amissis supervenit caecitas. Unde si oculi natura no fuisset corruptioni obnoxia, non patuisset aditus caecitati. Sic etiam malum non in propria substantia exsistit, sed ex animae laesionibus accedit. Neque enim ingenitum est, velut dicunt impii qui naturam malam bonae aequalem constituunt, si quidem utraque principio caret, anteceditque generationem; neque genitum est. Etenim si ex Deo sunt omnia, quamodo malum ex bono est? Neque enim turpe ex honesto est, neque vitium ex virtute".

[69] St. Maximus the Confessor, Quaestines ad Thalassium de Scriptura sacra, Quaestione, XXI, în J.P. Migne, PG. vol. 90, col. 244-785; St. Gregory of Nyssa,( De hominis opificio, in J.P. Migne, PG. vol. 44, col. 123-247; In Cantica Canticorum, PG. 44, col. 755-1118; De Verginitatem, PG, vol. 46, col. 317-416; Oratio Catechetica, în J.P. Migne PG. vol. 45, col. 11-107) St. John Chrysostom ( Homiliae XXX in Epistolam secundam ad Corinthios, in J.P. Migne, PG. vol. 61, col. 381-610; Homiliae in Genesim, PG. vol. 53); St. Gregory Palamas (Homiliae XXX, în J.P. Migne, PG. vol. 151, col. 375-388); St. Athanasius the Great, De incarnationem Verbi, în J.P. Migne, PG., vol. 25, col. 94-196; Dionysius the Areopagite, De divinis nominibus, în J.P. Migne, PG. vol. 3, col. 586-997;

[70] St. Augustine, De libero arbitrio, în J.P. Migne, PL. vol. 32, col. 1221-1310; Idem, Sermones 174, II, în J.P. Migne, PL. vol. 38, col. 939-945; St. Anselm of Canterbury (Anselmus Cantuariensis), Cur Deus homo, în PL. vol. 158, col. 360-432; Tomasso d'Aquino, Somma Teologica, Fiesole-Firenze, Edizione Angelo Zelio Belloni, 2009.

[71] St. Basil the Great, Homiliae: Quod Deus non est auctor malorum, 5, PG. 31, col. 338D: "Non autem ex Deo malum est". 
[72] Nikolaos Matsoukas, Dogmatic Theology and Symbolics IV. Demonology, (hence Demonology) translated by Constantin Coman and Cristian-Emil Chivu, București, Edit. Bizantină, 2002, p. 48.

[73] St. Basil the Great, Contra Eunomium, în J.P. Migne, PG. vol. 29, col. 468-774, aici col. 659A: "Nam cum res duae dicantur, deitas et creatura, dominium et servitus, potentia sanctificans, et santificatur".

[74] N. Matsoukas, Teologia dogmatica e simbolica ortodossa, 2, p. 22.

[75] Sf. Gregory of Nyssa, De Vita Moysis, în J.P. Migne. vol. 44, col. 298-433, aici col. 334B: "Nothing of what falls under the senses and, from what is known, through understanding really subsists except the Supreme Being, who is the cause of everything and of whom everything else hangs. For although understanding sees also something else of what it is, in none of what exists reason cannot see a thing to need something else, or what could be without participating at what it is." ( Nihil earum rerum, quae aut sensu comprehenduntur, aut mente perspiciuntur, praeter supremam essentiam, quae omnium causa est, et a qua omnia dependent, vere subsistere. In nullo enim caeterorum independentia perspici potest, ita ut absque partecipatione veri entis possit esse.)

[76] St. Augustine, De Nuptiis et Concupiscentia Liber II, c. XXIX, 50, în J.P. Migne, PL. vol. 44, col. 465: "Non enim ortum est malum nisi in bono, nec tamen summo et immutabili, quad est natura Dei; sed facto de nihilo per sapientiam Dei.",

[77] Idem, Contra Secundam Juliani responsionem imperfectum opus, Liber V, în J.P. Migne, PL. vol. 45,col. 1470: "Peccare autem nulla res posset, si de natura Dei facta esset".

[78] Idem, Moribus Manichaeorum, Liber II, în J.P. Migne, PL. vol. 32, col. 1347: "Quae aliud dicit bonum summe ac per se bonum est, et non partecipatione alicuius boni, sed propria natura et essentia: aliud quod participando bonum et habendo".

[79] C. C. Pavel, Introducere în gândirea Fericitului Augustin, p. 105.

[80] St. Irenaeus, Contre les Heresies IV, 38, în "Sources Chretiennes", nr. 100(2), sous la direction de Adelin Rousseau, Paris, Edition du Cerf,1965, p.362-995, aici p. 945.

[81] St. Augustine, Moribus Manichaeorum, PL. 32, col. 1347.

[82] St. John Damascene, Expositio Fidei Orthodoxae, I, 3, col.795: "Increratus cum sit ille conditor, omnino nec mutabilis est. Hoc autem quid aliud, nisi Deus fuerit?"; vezi și Fer. Augustin, Contra Secundam Juliani responsionem imperfectum opus, Liber V, col. 1475:"Omne quod peccare potest, ex nihilo factum esse, non autem omne quod ex nihilo factum est, posse peccare?"; Ibidem, cap. 44, col. 1481:"Cum itaque dicimus, non ideo potuisse oriri ex bono malam voluntatem, quia de nihilo factum est, non de Deo; non nihilo damus ullam naturam, sed naturam factoris a natura eorum quae sunt facta dicerimus".

[83] N. Matsoukas, Teologia dogmatica e simbolica ortodossa, 2, p. 91.

[84] Idem, Demonologia, p. 49; see also C. C. Pavel, Introducere în gândirea Fericitului Augustin, p. 106.

[85] Dionysius the Areopagite, De divinis nominibus, VIII, 6, col. 894C: "If, by consequence, the truth is what exists, and his negation is the coming out of existence, God cannot get out of existence and is not nonexistence; ( Si itaque veritas est id quod est, negatio autem veritatis, est ab essendi statu prolapsio, utique essendi statu frustrari Deus nequit, neque potest esse)"

[86] St. Augustine, De natura Boni. Contra Manichaeos, cap. I., în J.P. Migne, PL. 42, col. 551.

[87] C. C. Pavel, Introducere în gândirea Fericitului Augustin, p. 106.

[88] St. Augustine, De natura Boni. Contra Manichaeos, cap. I., PL. 42col. 551.

[89] Pr.dr. Ioan Chioar, Binele și răul în viziunea creștină (The Good and the Evil in the Christian View), București, Editura Universală Iași, 1996, p. 103.

[90] St. John Damascene, De imaginibus oratio, III, 25, în J.P. Migne, PG. 94, col. 1346A:"Deus siquidemsuapte natura, modisque omnibuz incorporeus est: angelus vero, et anima, et daemon, si cum Deo, qui solus incomparabilis est, componantur, corporibus accenseri possunt: sin autem cum corporibus, res sunt incorporeae"("For God is out of his nature and totally non-bodily"); Idem, Expositio Fidei Orthodoxae, II, 3, col. 867A: "Aliqui enim quidquid cum Deo confertur, qui solus nulli comparari potest, crassum et materiale invenitur. Sola quippe divina natura vere materia et corpore vacat" (" Everything that compares with the Lord God, who is incomparable, is bodily, « has thickness » and material, for only God is genuinely immaterial and non-bodily")

[91] St. Basil the Great, Contra Eunomium, III, 2, col. 659C:"Non enim excidisset Lucifer, qui mane oritur, nec esset in terra contritus, si deterioris conditionis recipiendae non fuisset capax natura."

[92] N. Matsoukas, Demonologia, p. 49.

[93] D. Stăniloae, Teologie Dogmatică Ortodoxă, I, 2003, p. 477: vezi și C.C. Pavel, Introducere în gândirea Fericitului Augustin, p. 123: "The cause of evil is vanity, the pretention of considering himself the source of life". 
[94] St. Basil the Great, Homiliae: Quod Deus non est auctor malorum, cap. 8, col. 346D-347A: "Unde malus diabolus? Ex esadem causa, cum et ipse liberam vitam haberet, ac penes se esse vel Deo perseveranter adhaerere, vel a bobo secedere. Gabriel angelus est, et Deo jugiter astitit. Satana serat angelus quoque, sed ex suo ordine penitus excidit. Et illum retinuit in caelis liberum arbitrium, et hunc dejecit voluntatis libertas. Poterat namque et ille desciscere, et hic non labi. Sed illum servavit Dei dilectio insatiabilis, hunc vero reprobum fecit suus a Deo recessus. Hoc est malum, abalienatio a Deo. Parva oculi conversio facit, ut aut cum sole, aut cum corporis nostri umbra simus. Et illuc quidem si respicias, prompte ac cito illustraris: ad umbram vero si declines, necessario degis in tenebris."

[95] St. Augustine, De civitate Dei, în J.P. Migne, PL, vol. 41, col. 700-712.

[96] N. Matsoukas, Teologia dogmatica e simbolica ortodossa, 2, p. 109. 